\title{
A GIS-AHP Based Approach for Optimal Quarry Site Location Around Harer and Dire-Dawa Towns, Eastern Ethiopia
}

\author{
Leta Gudissa ( $\sim$ letagudissa13@gmail.com ) \\ Addis Ababa Science and Technology University https://orcid.org/0000-0003-2549-7503 \\ Tarun Kumar Raghuvanshi \\ Addis Ababa university, School of Earth Sciences, College of Natural Sciences \\ Matebie Meten \\ Addis Ababa Science and Technology University, Department of Geology, College of Applied Sciences \\ Yadeta Chemdesa Chemeda \\ Adama Science and Technology University, Department of Applied Geology, School of Natural Sciences
}

\section{Research}

Keywords: Aggregate quarry, Analytic Hierarchy Process (AHP), Suitability analysis, weighted overlay

Posted Date: August 27th, 2020

DOI: https://doi.org/10.21203/rs.3.rs-58834/v1

License: @ (i) This work is licensed under a Creative Commons Attribution 4.0 International License. Read Full License 


\section{Abstract}

The scarcity of lands for suitable quarry sites is rapidly becoming a critical growing problem in most developing countries of the world. Therefore, selection of optimal quarry sites for crushed aggregates is a prerequisite for safe operation and economic viability. The present study was carried out around Harer and Dire-Dawa towns located about 520 km from Addis Ababa. The main objective of the study was to identify optimal location of quarry sites for crushed aggregates by using integrated Analytic Hierarch Process (AHP) and GIS approach. Selection was carried out by considering factors such as lithology, land-use and land-cover, distance to built-up areas, distance to water bodies, distance to roads, relative relief, and slope angle. For each of the factors appropriate classifications and criteria were formulated based on its suitability. Finally, by utilizing all factors, weighted overlay analysis was applied to produce the quarry site suitability map. The resulted suitability map shows about $136 \mathrm{~km}^{2}$ of the area is highly suitable, $1,587 \mathrm{~km}^{2}$ is moderately suitable, and $2,166 \mathrm{~km}^{2}$ has low suitability for quarry site development. The findings of the study will be helpful in narrowing down the area to the suitable areas that may further be studied through detailed field investigation. This result will also greatly serve as guide in quarry site selection in other states and/or other developing countries.

\section{Introduction}

The menace of environmental degradation and pollution resulting from quarry operation has been a threat to the inhabitants of most developing countries and its harmful effects on the major roads, power lines, built ups, and water environment are considered to be frightening. As a result of quarrying natural habitats and features such as; hedgerows and trees can be removed (Saha and Padhy 2011). Quarrying activities have the potential to impact an area of valuable habitat, particularly when it is located in the vicinity of such habitats. Habitats outside the quarry site can be impacted indirectly by dust deposition, alteration of the water supplies, or as a result of run-off or siltation (Ogbonna et al. 2019). The archaeological heritage is a non-renewable resource therefore; the presence of known archaeological sites must be an essential consideration during the selection of quarry sites (Akanwa et al. 2017; Kindiga 2017; Barakat et al. 2016; Regessa et al. 2015; Zaruba and Mencl 1976). Similar considerations apply in the case of protected structures. Blasting at quarries can give rise to vibration, noise, fly rock, and dust. Noise can cause annoyance; nuisance, and sleep disturbance. Residential, schools, hospitals, churches, etc. are noise-sensitive receptors. Thus, for the extraction of dimension stones, aggregates for concrete pavement, railway ballast and other construction materials, selection of suitable quarry site is essential. A quarry is an open pit used for mining of rock or minerals for various purposes. Most communities all over the world are often faced with task of making a suitable decision when finding the most appropriate sites for new quarry as process of making choice is a complex procedure since social, environmental and technical factors must be considered together (Ming'ate and Mohamed 2016). In most of the African nations, the selection of quarry sites and its operations and management do not take into account the environmental sustainability (Darwish et al. 2011). Generally, the methods followed for resource extraction are poor and the site selection for quarrying are not made through systematic methods. Very often this leads to land collapse, land conversion, environmental pollution and may also affect the people residing in the nearby localities (Pal and Mandal 2019; Ethirajan and Mariappan 2018). Thus, need for proper site selection, quarrying planning and management is essential not only for successful quarry operations but also it is equally important for quality control and sustainable environmental management (Egesi and Nwosu 2018).

Rocks for aggregates are quarried through blasting using explosives and/ or mechanical excavation by using machineries. The aggregate production from the rock involves mechanical crushing, screening, loading, and transportation processes (Langer et al. 2004). The quarry excavation may cause land conversion of previous land use and possibly lead to environmental degradation, if quarrying is not well planned and managed (Ming'ate and Mohamed 2016). The primary sources of crushed aggregate are the alluvial deposits and various types of rocks such as; basalt, gneiss, dolomite and limestone etc (Barakat et al. 2016).

For suitable quarry site selection various factors can be considered such as; lithology, land-use and land-cover, distance to built-up area, distance to streams/ water bodies, distance to roads, relative relief and slope angle. These factors may possibly influence quarry site with respect to its geotechnical, economic and environmental suitability during its operational and decommissioning phases of materials extraction. In order to apply these factors to identify suitable quarry sites, systematic framework through Analytical Hierarch Process (AHP) can be applied. AHP is a technique which can be applied in a GIS environment that provides a flexible and easily understandable way of analyzing complicated problems that allows subjective as well as objective factors to be considered in a decision-making process (Kou et al. 2016; Vaidya and Kumar 2006; Dey and Ramcharan 2008).

Page $2 / 21$ 
For natural aggregate production tremendous time and money is spent in locating potential aggregate resources and in determining their quantity and quality (Langer et al. 2004; Langer and Tucker 2003). Besides, efforts are also made to determine the feasibility of production, environmental impact assessment, fulfillment of the norms set as mining laws, in procurement of permit for mining operation, processing and transportation. The first step in aggregate exploration is a preliminary geological, geotechnical, environmental and economic evaluation. The preliminary investigations are followed by detailed studies that involve satellite image interpretation and field reconnaissance studies of target areas to define the limits of the potential sources of aggregate. According to Barakat et al. (2016), rocks exposed at higher elevations are less desirable for quarrying operations because of poor accessibility and high transportation costs. Similarly, rocks forming steep slopes are susceptible for instability (Raghuvanshi 2019; Barakat et al. 2016; Raghuvanshi et al 2014; Anbalagan 1992; Tan 1984) therefore such steep slopes may not be feasible for quarrying operation and may further pose problems in accessibility and developing roads on steep slopes may incur additional cost to the project.

According to Akanwa et al. (2017) quarry operations may leads to loss of vegetation cover. Moreover, Subhasis et al. (2018); SOPAC (2005) indicated that quarry operations have impact on environment through air, noise pollution and vibrations. According to Langer et al. (2004), changing a landscape from agricultural lands to a quarry is also an obvious impact of quarrying. Further, it is required to assess the potential impacts of quarrying activities on soil and water resources, and on the populated areas so that anticipated risks due to potential quarry sites may be minimized (Pal and Mandal 2019; Regessa et al. 2015; Darwish et al. 2011). Further, Barakat et al. (2016); Regessa et al. (2015); Tan (1984) has identified prominent parameters such as; slope angle, elevation difference, land-use and land-cover and rock type have significant effect on the suitability and feasibility of quarry site.

Integrated Analytic Hierarch Process (AHP) with GIS has been adopted in previous works for selection of groundwater recharge site (Rajasekhar et al. 2019), land fill site (Akanwa et al. 2017; Dimopoulou et al. 2013; Ebistu and Minale 2013; Zelenović et al. 2012; Yoxas et al. 2011; Ketema 1982), and for selection of mining methods (Mandal and Mondal 2016; Ataei et al. 2008). In Ethiopia not much previous studies were carried out to identify suitable quarry sites by following systematic criteria based expert judgment. A study carried out by Regessa et al. (2015) followed the criteria based quarry sites selection procedure to select potential quarry sites for ballast aggregate. For selection of suitable quarry sites in the study area they formulated selection criteria and applied it in GIS environment. Another study was carried out by Getahun (2010) in which multi-criteria approach was used to select the appropriate quarry sites by using GIS and Remote Sensing approach. To prepare the suitability map weighted linear combination method was used and a pair-wise comparison matrix was developed for the selected parameters. However, integrated AHP and GIS approach has not been adopted in aggregate quarry site selection, particularly in Ethiopia. Therefore, the main objective of the present study was to identify suitable potential quarry sites for crushed aggregates by using integrated Analytic Hierarch Process (AHP) and GIS approach.

\section{Description Of The Study Area}

The study area is located in the Eastern part of Ethiopia, about $520 \mathrm{~km}$ from Addis Ababa. The area is bounded by UTM coordinates of 746247-886247E and 994861-1084861N (Fig. 1). Harer town is accessible from Addis Ababa through asphalt road, where as Dire-Dawa town can be accessed either by road, by air or by train. Topography of the area is characterized as rugged with elevation ranging from 976 to 3378 masl. Ahmar mountain chain which runs from east to west along the margin of the eastern plateau is a distinct physiographic highland feature in the study area. The northern part of the study area forms the valley whereas; southern area is characterized by gently undulating surfaces and occasionally cliffs.

The present study area is situated in "kola" agro-climatic region. The temperature is hot throughout the year with minor seasonal variations and progressively increasing temperatures towards northward. The rainy seasons are from March to September, with an irregular rainfall during February to May and a regular maximum rainfall from July to September. The mean annual rainfall is $850 \mathrm{~mm}$ and the mean annual temperature is $25^{\circ}$. June is the warmest month in the year while December and January are the coldest.

\section{Geology Of The Study Area}


The regional geology of Harer and Dire-Dawa area ranges from Precambrian basement rocks up to recent sediments (Fig. 2). The Precambrian rocks include Archean high-grade gneisses and migmatites, Archean amphibolite rock and Proterozoic rocks (lowgrade quartz-mica schist: schistose fine-grained rock, pelitic and psammitic biotite schist, amphibole schist, quartzites, and marbles). In the study area, Precambrian-Proterozoic massive granite is exposed on elevated portions and is underlying the lower sandstone. The rocks belonging to upper Paleozoic, Soka Group, includes phyllite, greenstone, chert, serpentinites, and talc schist is also exposed in the study area. The Mesozoic succession of Dire-Dawa and Harar province consists of lower fluviatile sandstone, carbonate, and upper fluviatile sandstone (Bosellini et al. 2001). Cenozoic volcanic rocks (oligocene) Alaji basalt, and (middle Miocene) Tarmaber basalts are exposed at plateau. The rift plain and parts of major eroded valleys on the plateau contain Quaternary alluvial sediments of lacustrine origin. Further, re-deposited valley sediments occur on gentle slopes, interfluves and wide valley floors both on the plateau and the rift zones (GSE 2010).

The local geology of the study area is dominantly covered by the Antalo limestone (Fig. 2). Gildessa limestone, exposed in northeast of Dire-Dawa town consists of massive grainstone, oolitic coarse grainstone, parallel and cross lamination with marine coral fragments. It also consists of Dire-Dawa Formation which is black micritic limestone and marls rich in belemnites, ammonites and Gryphaea and marly limestone. The Antalo limestone overlies the lower Adigrat sandstone unit. The topmost part of the limestone is weathered and the limestone in the Dire-Dawa area mostly covers the escarpment zone (Ketema 1982). Well sorted upper sandstone of the Mesozoic Era is also exposed around Dire-Dawa town and overlies the Antalo limestone.

The main geologic structures present in the limestone unit are joints, solution cavities, and karstification. These structures are developed along the bedding planes and along the major tectonic directions. The limestone beds around Dire-Dawa town dip towards south and southwest and strike east-west and NW-SE direction. The limestone beds have usually a horizontal orientation (dips below $10^{\circ}$ ). Major joints run in N-S direction along with the Ethiopian rift system while minor joint sets are perpendicular to the major joints (Ketema 1982).

\section{Materials And Methods}

\section{Materials}

The supporting materials and analytical tools used in the present study are: topographic map at a scale of 1:50,000, Landsat 8 images, Google Earth images and Digital Elevation Model (DEM) extracted from ASTER data set and Geological map of Dire Dawa and Harer sheets (scale of 1:250,000) prepared by GSE in 2010. Further, Arc GIS, ERDAS Imagine and Global Mapper software were used for the preparation of various maps used in the present study. Besides, IDRISI was also used for the computation of pair-wise comparison matrix for the factors. The geological map of the area was firstly georeferenced and subsequently digitized to show criteria features considered for selecting quarry site in the GIS environment.

\section{Methods}

In the present study systematic procedures were followed to meet out the objective of the study. The steps involved in the preparation of suitability map for quarry site are shown through flow chart (Fig. 3). The selection of suitable area for quarry sites require classification of selected factors and formulating weighted criteria by using GIS approach (Alanbari et al. 2014; Ebistu and Minale 2013; Zelenović et al. 2012; Yoxas et al. 2011).

The Landsat 82018 (path 167, row 53 and 54) was used to prepare the land-use and land-cover (LULC) map of the study area. A tentative LULC thematic map was obtained from the false color composite of the image with $30 \mathrm{~m}$ resolution which was pan sharpened and redefined to $15 \mathrm{~m}$ resolution. Google Earth image was also used for controlling training pixels. Later, final verification and modifications of the prepared LULC map was done through field observation using GPS control points. Distance to existing roads was derived from the Ethiopian road network map prepared by Ethiopian Roads Authority (ERA) in 2006 at a scale of $(1: 2,000,000)$, topographical maps $(1: 50,000)$ and by Google earth image interpretations. The data for lithology was obtained from the geological map and the field visual observations. Geological maps of Harer and Dire Dawa sheet (1:250,000 scale) were mosaiced and refined to prepare the geological map of the study area. Later, the geological map was verified and modified through field observations. Further, distance to build up areas and distance to water bodies was extracted from the topographical maps $(1: 50,000)$ and the Google Earth images. Distance to roads was modified from the Ethiopian roads network map prepared by 
Ethiopian Roads Authority (ERA) in 2006 at a scale of $(1: 2,000,000)$. Slope angle and relative relief were extracted from ASTER GDEM data set at $15 \mathrm{~m}$ resolution and later reclassified for quarry site selection. Thus, desired thematic layers on lithology, distance to buildup areas, land-use and land-cover, distance to water body, distance to roads, relative relief, and slope angle were extracted. Later, all these thematic layers were processed in GIS and vector to raster conversion was made. Further, each of the thematic layers was reprocessed and classification was made.

\section{AHP Model}

For valuation of the criteria features, various methods such as logistic regression, AHP model, weight of evidence, ratio estimation and the Delphi process could be chosen (Adewumi et al. 2019). Several researchers have used AHP method of pair-wise comparison matrix, in order to assign the weights to each of the considered factors (Haile and Suryabhagavan 2019; Rajasekhar et al. 2019; Ramík 2017; Mandal and Mondal 2016; Ataei et al. 2008; Vaidya and Kumar 2006). The weights quantify the relative importance of the considered suitability criteria. The essence of pair wise comparison is that two criteria are evaluated at a time to determine their relative importance (Mayunga 2018; Vaidya and Kumar 2006). In this research, AHP model was adopted in order to give value to the criteria and select the best appropriate site. Once the hierarchy has been established, a pair wise comparison matrix of each element within each level is constructed. This pair-wise comparison permits for an independent rating of each factor's contribution, which therefore simplify the decision-making process (Adewumi et al. 2019). The eigenvalue of the comparison matrix gave the relative importance of the criteria being compared. Participants can weigh each element against each other within each level, which is related to the levels above and below it, and mathematically tie the entire scheme together. The consistency check offered by AHP makes it a unique tool in the decision-making since it allows improvement in making decision. The consistency of the weight for various factors was checked through, a single numerical value, the consistency ratio (CR), which measures the level of inconsistency of the pair wise comparison matrix (i.e. the likelihood whether factor weights were randomly assigned). The consistency ratio (CR) can be defined by the mathematical relation equation (Vaidya and Kumar 2006);

$$
C R=\frac{C I}{R I}
$$

Where $\mathrm{Cl}$ is the consistency index and $\mathrm{RI}$ is random consistency index of a comparison matrix. $\mathrm{Cl}$ was computed as:

$$
C R=\frac{\lambda_{\max }-\eta}{\eta-1}
$$

Where ' $\lambda_{\max }$ ' is the largest eigenvalue of the comparison matrix and ' $n$ ' is the number of criteria or factors.

AHP is a powerful and popular technique which can be applied in a GIS environment and provides a means for analyzing complicated problems that allows subjective as well as objective factors to be considered in a decision-making process (Haile and Suryabhagavan 2019; Kou et al. 2016; Jablonsky 2015; Dimopoulou et al. 2013; Vaidya and Kumar 2006).

Formulating quarry site selection criteria based on classification and reclassification of values into certain ranges with regard to suitability was a crucial component for identifying suitable areas for quarry sites. Once the weighting was worked out and criteria for classification was formulated; the next step involved was the creation of individual thematic layers or factor maps to be overlaid. Finally, by weighted overlay analysis and integrating the entire thematic factor layers, quarry sites suitability map was prepared.

Some areas with restrictions such as very low cohesive rocks (alluvium, elluvium and lake sediments), some land uses (residential areas, protected areas), etc are removed from whole considered area according to Boolean logic.

The considered factors for quarry site suitability map preparation, their significance and relative order of importance is presented in Table 1. 
Table 1

Factors for quarry site suitability map preparation, their significance and order of importance

\begin{tabular}{|c|c|c|c|}
\hline $\mathrm{S} / \mathrm{N}$ & Factors & Significance & $\begin{array}{l}\text { Order of } \\
\text { importance }\end{array}$ \\
\hline 1 & Lithology & $\begin{array}{l}\text { Lithology is the most important factor governing the quality of rock; for example; some } \\
\text { flaky, soft and friable rocks cannot be used as aggregate. }\end{array}$ & $\begin{array}{l}\text { Extremely } \\
\text { strong } \\
\text { influence }\end{array}$ \\
\hline 2 & $\begin{array}{l}\text { Land-use } \\
\text { and land- } \\
\text { cover }\end{array}$ & $\begin{array}{l}\text { Environmental code of practices preserves and protects cultural heritages, } \\
\text { archeological sites, parks and built-up areas. Thus, LULC may totally prohibit the } \\
\text { development of quarry site even when good quality and quantity material is available. }\end{array}$ & $\begin{array}{l}\text { Very strong } \\
\text { importance } \\
\text { over the rest }\end{array}$ \\
\hline 3 & $\begin{array}{l}\text { Distance } \\
\text { to build } \\
\text { up area }\end{array}$ & $\begin{array}{l}\text { Community safety is a sensitive issue showing strong influence on quarry site } \\
\text { suitability. However, it does not prohibit the development of quarry site. Quarrying can } \\
\text { be possible with appropriate environmental protection and by adopting suitable } \\
\text { mitigation measures. }\end{array}$ & $\begin{array}{l}\text { Strong } \\
\text { influence }\end{array}$ \\
\hline 4 & $\begin{array}{l}\text { Distance } \\
\text { to water } \\
\text { bodies }\end{array}$ & $\begin{array}{l}\text { Lakes and streams are more susceptible to pollution as runoff from quarry sites flow } \\
\text { very rapidly into them. Thus, a safe distance to water bodies needs to be maintained } \\
\text { from the quarry sites. }\end{array}$ & $\begin{array}{l}\text { Moderately } \\
\text { more important }\end{array}$ \\
\hline 5 & $\begin{array}{l}\text { Distance } \\
\text { to roads }\end{array}$ & $\begin{array}{l}\text { Distance to roads is an important factor. Close proximity of road to the quarry site may } \\
\text { result into dangers of fly rock due to blasting and air pollution. Roads at far distance } \\
\text { may result into additional project cost due to development of new roads and increased } \\
\text { transportation cost. }\end{array}$ & $\begin{array}{l}\text { Least } \\
\text { important but } \\
\text { more important } \\
\text { than Relative } \\
\text { relief }\end{array}$ \\
\hline 6 & $\begin{array}{l}\text { Relative } \\
\text { relief }\end{array}$ & $\begin{array}{l}\text { Important from slope instability point of view, flooding potential, ease of excavation } \\
\text { and inaccessibility. }\end{array}$ & $\begin{array}{l}\text { Moderately } \\
\text { important than } \\
\text { Slope angle }\end{array}$ \\
\hline 7 & $\begin{array}{l}\text { Slope } \\
\text { Angle }\end{array}$ & Induce slope instability but is not the sole factor that triggers the instability. & $\begin{array}{l}\text { Relatively least } \\
\text { effect }\end{array}$ \\
\hline
\end{tabular}

The data processing was mainly done for classification and reclassification of various factor maps in GIS environment. Later, appropriate weights were assigned to the processed factor maps. Besides, consistency of the weight assigned to various factors was also checked. In the present study standardization of heterogeneous input data into a uniform scale for all layers were used; particularly 1 by 7 by 1 scaling method was adopted (Table 3 ). While assigning the ratings to various factors it is important to know the suitability of various factor classes.

\section{Reclassification of thematic layers}

Reclassification of thematic layers facilitates the interpretation of raster data by changing a single input value into a new output value. It also helps to group ranges of cell values into a single value. This simplifies weighted analysis as different types of raster data in different factor sub-classes may represent different conditions. Thus, by using reclassification for each thematic layer, ranking scheme based on pre defined weights can be used to work out least and most suitable conditions (Anbalagan 1992). All thematic maps were prepared, geo-processed, reclassified in GIS environment and vector to raster conversion was made. The geological map of the study area was reclassified into seven lithological classes. These classes are; (i) Basalt, (ii) Limestone, Travertine and Dolomite, (iii) Granite, (iv) Gneiss and Amphibolites, (v) Schist, Phyllites, Greenstone, Chert, Serpentinites and Talc, (vi) Detrital Sandstone, Conglomerates and Shales and (vii) Lake sediment, Alluvium and Elluvium products. This re-classification was mainly done based on the relative suitability of each lithological unit for the quarry site selection (Table 2). The distribution of these lithological units in the study area is shown through Fig. 4 (a). 
Table 2

Factors and factor class suitability and ratings

\begin{tabular}{|c|c|c|c|c|c|c|c|}
\hline Factors/ factor classes & Description & Suitability & $\mathbf{R}$ & $\begin{array}{l}\text { Factors/ } \\
\text { factor } \\
\text { classes }\end{array}$ & Description & Suitability & $\mathbf{R}$ \\
\hline \multicolumn{4}{|l|}{ Lithology } & \multicolumn{4}{|c|}{ Distance to Road (m) } \\
\hline $\begin{array}{l}\text { Lake sediment, } \\
\text { Alluvium and Elluvium } \\
\text { products }\end{array}$ & $\begin{array}{l}\text { Easily disintegrate, contain } \\
\text { heterogeneous layers (clay } \\
\text { and silt) }\end{array}$ & Unsuitable & 0 & $<500$ & Too short & Unsuitable & 0 \\
\hline $\begin{array}{l}\text { Detrital Sandstone, } \\
\text { Conglomerates and } \\
\text { Shales }\end{array}$ & Soft and friable & Very low & 1 & $>10000$ & Far away & Very low & 1 \\
\hline $\begin{array}{l}\text { Schist, Phyllites, } \\
\text { Greenstone, Chert, } \\
\text { Serpentinites and Talc }\end{array}$ & $\begin{array}{l}\text { Highly foliated rock, weak, } \\
\text { flaky, contains chlorite and } \\
\text { micas }\end{array}$ & Low & 2 & $\begin{array}{l}10000- \\
7500\end{array}$ & & Low & 2 \\
\hline $\begin{array}{l}\text { Gneiss and } \\
\text { Amphibolites }\end{array}$ & Poorly foliated rock; flaky & Moderate & 3 & $\begin{array}{l}7500- \\
5000\end{array}$ & Intermediate & Moderate & 3 \\
\hline Granite & $\begin{array}{l}\text { Coarse grained, non } \\
\text { crushable, contains K- } \\
\text { feldspar, porphroblasts and } \\
\text { quartz }\end{array}$ & High & 4 & $\begin{array}{l}5000- \\
3200\end{array}$ & $\begin{array}{l}\text { Fairly far } \\
\text { away }\end{array}$ & High & 4 \\
\hline $\begin{array}{l}\text { Limestone, Travertine } \\
\text { and Dolomite }\end{array}$ & Massive and easily crushed & Very high & 5 & $\begin{array}{l}3200- \\
1600\end{array}$ & & Very high & 5 \\
\hline Basalt & $\begin{array}{l}\text { Igneous dark fine-grained } \\
\text { rock }\end{array}$ & Extre. high & 6 & $\begin{array}{l}1600- \\
500\end{array}$ & & Extre. high & 6 \\
\hline \multicolumn{4}{|l|}{ Land-use/ land-cover } & \multicolumn{4}{|c|}{ Relative Relief (m) } \\
\hline $\begin{array}{l}\text { Protected areas, } \\
\text { structures, and } \\
\text { settlement }\end{array}$ & $\begin{array}{l}\text { Monument, Cave, Air field, } \\
\text { and housing }\end{array}$ & Unsuitable & 0 & $<5$ & Extre. low & Unsuitable & 0 \\
\hline Forest & Thickly vegetated land & Very low & 1 & $>300$ & Extre. High & Very low & 1 \\
\hline $\begin{array}{l}\text { water bodies and } \\
\text { wetland }\end{array}$ & $\begin{array}{l}\text { Lakes, streams, major rivers } \\
\text { and wet lands }\end{array}$ & Low & 2 & $\begin{array}{l}200- \\
300\end{array}$ & Very high & Low & 2 \\
\hline Cultivated land & Arable land by plowing & Moderate & 3 & $\begin{array}{l}100- \\
200\end{array}$ & High & Moderate & 3 \\
\hline Shrubs & $\begin{array}{l}\text { Scattered vegetation in the } \\
\text { form of wild grass, bushes, } \\
\text { and small trees }\end{array}$ & High & 4 & $50-100$ & Moderate & High & 4 \\
\hline Sand cover & $\begin{array}{l}\text { No vegetation and the bed } \\
\text { rock covered by sand }\end{array}$ & Very high & 5 & $25-50$ & Low & Very high & 5 \\
\hline Bare land & No vegetation cover & Extre. high & 6 & $5-25$ & Very Low & Extre. high & 6 \\
\hline \multicolumn{4}{|c|}{ Distance to build up area (m) } & \multicolumn{4}{|c|}{ Slope angle $\left({ }^{(}\right)$} \\
\hline$<1000$ & Very close & Unsuitable & 0 & $<5$ & Extre. gentle & Unsuitable & 0 \\
\hline$>2500$ & Far away & Very low & 1 & $>60$ & $\begin{array}{l}\text { High } \\
\text { escarpment }\end{array}$ & Very low & 1 \\
\hline $2500-2200$ & & Low & 2 & $60-45$ & $\begin{array}{l}\text { Escarpment } \\
\text { or Cliff }\end{array}$ & Low & 2 \\
\hline $2200-1900$ & Intermediate & Moderate & 3 & $45-35$ & Steep & Moderate & 3 \\
\hline $1900-1600$ & Fairly far away & High & 4 & $35-25$ & $\begin{array}{l}\text { Moderately } \\
\text { steep }\end{array}$ & High & 4 \\
\hline
\end{tabular}




\begin{tabular}{|c|c|c|c|c|c|c|c|}
\hline Factors/ factor classes & Description & Suitability & $\mathbf{R}$ & $\begin{array}{l}\text { Factors/ } \\
\text { factor } \\
\text { classes }\end{array}$ & Description & Suitability & $\mathbf{R}$ \\
\hline $1600-1300$ & & Very high & 5 & $25-15$ & Gentle & Very high & 5 \\
\hline $1300-1000$ & Not far not Close & Extre. high & 6 & $15-5$ & Very gentle & Extre. high & 6 \\
\hline \multicolumn{8}{|c|}{ Distance to water bodies (m) } \\
\hline$<150$ & Very Close & Unsuitable & 0 & & & & \\
\hline $150-300$ & \multirow[t]{2}{*}{ Close } & Very low & 1 & & & & \\
\hline $300-450$ & & Low & 2 & & & & \\
\hline $450-600$ & Intermediate & Moderate & 3 & & & & \\
\hline $600-750$ & \multirow[t]{3}{*}{ Far away } & High & 4 & & & & \\
\hline $750-900$ & & Very high & 5 & & & & \\
\hline$>900$ & & Extre. high & 6 & & & & \\
\hline
\end{tabular}

Table 3

Weights assigned, consistency ratio (CR), pair wise comparison matrix, and scaling to assign rating value

\begin{tabular}{|c|c|c|c|c|c|c|c|c|c|c|}
\hline \multicolumn{11}{|c|}{ Pair wise Comparison - 9 Point Continuous Rating Scale } \\
\hline $1 / 9$ & $1 / 7$ & \multicolumn{2}{|l|}{$1 / 5$} & $1 / 3$ & \multicolumn{2}{|l|}{1} & 3 & 5 & 7 & 9 \\
\hline Extremely & $\begin{array}{l}\text { Very } \\
\text { strongly }\end{array}$ & \multicolumn{2}{|c|}{ Strongly } & Moderately & \multicolumn{2}{|c|}{ Equally } & Moderately & Strongly & $\begin{array}{l}\text { Very } \\
\text { strongly }\end{array}$ & Extremely \\
\hline \multicolumn{7}{|c|}{ Less Important } & \multicolumn{4}{|c|}{ More Important } \\
\hline \multicolumn{11}{|c|}{ Order of Importance and Rating Assigned } \\
\hline Unsuitable & \multicolumn{2}{|c|}{$\begin{array}{l}\text { V. Low } \\
\text { suitable }\end{array}$} & Low suitable & & \multicolumn{2}{|c|}{$\begin{array}{l}\text { Moderately } \\
\text { suitable }\end{array}$} & \multicolumn{2}{|c|}{ Highly suitable } & $\begin{array}{l}\text { V. highly } \\
\text { suitable }\end{array}$ & $\begin{array}{l}\text { Extremely } \\
\text { suitable }\end{array}$ \\
\hline 0 & 1 & 2 & 2 & 3 & & & 4 & 5 & 6 & \\
\hline \multicolumn{11}{|c|}{ Pair wise Comparison - Matrix } \\
\hline Attributes & $\mathrm{LI}$ & LU & DB & DW & DR & $\mathrm{RR}$ & SA & & $\begin{array}{l}\text { Eigenvector } \\
\text { weights }\end{array}$ & Weight (\%) \\
\hline $\mathrm{LI}$ & 1 & - & - & - & - & - & - & & 0.3543 & 35 \\
\hline LU & $1 / 2$ & 1 & - & - & - & - & - & & 0.2399 & 24 \\
\hline DB & $1 / 3$ & $1 / 2$ & 1 & - & - & - & - & & 0.1587 & 16 \\
\hline DW & $1 / 4$ & $1 / 3$ & $1 / 2$ & 1 & - & - & - & & 0.1036 & 10 \\
\hline DR & $1 / 5$ & $1 / 4$ & $1 / 3$ & $1 / 2$ & 1 & - & - & & 0.0676 & 7 \\
\hline $\mathrm{RR}$ & $1 / 6$ & $1 / 5$ & $1 / 4$ & $1 / 3$ & $1 / 2$ & 1 & - & & 0.0447 & 5 \\
\hline \multirow[t]{3}{*}{ SA } & $1 / 7$ & $1 / 6$ & $1 / 5$ & $1 / 4$ & $1 / 3$ & $1 / 2$ & 1 & & 0.0312 & 3 \\
\hline & & & & & & & Total & & 1 & 100 \\
\hline & & & & & \multicolumn{4}{|c|}{ Consistency ratio (CR) } & 0.02 & $\begin{array}{l}\text { consistency } \\
\text { is } \\
\text { acceptable }\end{array}$ \\
\hline
\end{tabular}

Note: $\mathrm{LI}=$ Lithology; $\mathrm{LU}=\mathrm{Land}$ use/land cover; $\mathrm{DB}=$ Distance to buildup; $\mathrm{DW}=$ Distance to water body; $\mathrm{DR}=$ Distance to road; $\mathrm{RR}=$ Relative relief; $\mathrm{SA}$ = Slope angle 
The Land-use/ land-cover (LULC) and distance to build up areas maps in general represent the environmentally sensitive ecosystem and more valuable land use practices. Before the actual use of the Landsat 8 image; a number of image preprocessing such as; layer stack and pan sharpen enhancements were done. Later the image was subset using the study boundary as an area of interest (AOI) and used in the supervised image classification. In the supervised image classification, a signature of what particular classes look like was provided, and the software algorithms subsequently has used this signature (training) to derive rules for mapping all other pixels into the class values. Thus, the resulting reclassified LULC map of the area is presented as Fig. 4 (b).

For the assessment of proximity to the built-up areas euclidean distance to populated centers was computed for each cell. The euclidean distance calculates, the distance of each cell to the closest settlement. A map of distance to build up areas helps to measure the vulnerability of the adjoining community to dust, noise and vibration hazards (Subhasis et al. 2018). Thus, for the present study distance to build up area was reclassified into seven classes based on the relative suitability of each sub-class for the quarry site selection. The various sub-classes for distance to buildup area and their relative suitability for quarry site are presented in Fig. 4 (c).

It is reasonable to say that water bodies very close to the quarry site will be susceptible to water pollution due to quarry operations while those which are relatively far will be free from pollution due to quarry operations. The water body map, prepared for the present study, was reclassified into seven classes based on the relative suitability of each sub-class for the quarry site selection. For the assessment of proximity to the water bodies euclidean distance tool in Arc GIS was used and the resulting map is presented as Fig. 4 (d).

The road map prepared during the present study was reclassified into seven classes based on the relative suitability of each subclass for the quarry site selection.

Relative relief and slope angle thematic maps were extracted facet wise from the DEM and later these thematic layers were reclassified as per the suitability for the quarry site selection (Fig. 4 (f) and (g)). Relative relief defines the elevation difference within a given slope (Ermias et al. 2017; Raghuvanshi et al. 2014; Anbalagan 1992). According to Raghuvanshi et al. (2014), relative relief for landslide hazard zonation is classified into classes; < 50 (low), 51-100 m (moderate), 101-200 m (medium), 201-300 m (high) and > $300 \mathrm{~m}$ (very high). In the present study for quarry site selection, the same criteria were adopted for reclassification of relative relief. However, the classification was made into seven classes as; $<5 \mathrm{~m}$ (extremely low), 5-25m (very low), 25-50 m (low), 50-100 (moderate), 100-200 m (high), 200-300 m (very high) and > 300 (extremely high).

For the classification of slope angle the works of (Barakat et al. 2016; Raghuvanshi et al. 2015; Raghuvanshi et al. 2014; Anbalagan 1992) were referred. The slope classification proposed by Raghuvanshi et al. (2014) was formulated for landslide hazard zonation and this classification is further refined for the present study to account for quarry site suitability. Thus, the slope angle was distributed into seven classes and their respective suitability is presented in Table 2.

For the suitable quarry site selection process, the input layers for all factors were processed and prepared in raster format. It was important to evaluate the accuracy of a classified image by using known ground truth locations and values before proceeding into the actual use of the image. Thus, 25 random points were selected and an accuracy assessment was made for the LULC classification using the Google earth image as a ground truth.

The order of importance obtained by AHP was converted to percent according to their relative influence, as the overlay analysis requires weight in percentages (Fig. 4). Thus, lithology, LULC, distance to build up area, distance to water bodies, distance to roads, relative relief and slope angle weights were computed as 35\%, $24 \%, 16 \%, 10 \%, 7 \%, 5 \%$, and $3 \%$, respectively. Decimal values were rounded off to the nearest integer. Later, a weighted suitability overlay analysis was made for each cell in GIS environment by the summation of the products of weight with the respective rating value of each factor.

The weighted overlay of the spatial analyst tool was used to overlay 7 raster layers using a common measurement scale based on their relative influence. To run the weighted overlay, all input raster layers must be an integer. The reclassification tool provides an effective way to do the conversion. During reclassification, each value class in an input raster was assigned with a new value based on an evaluation scale. 


\section{Results And Discussion}

In order to optimize suitable areas for quarry sites seven factors were considered. These factors are lithology, distance to buildup areas, land-use and land-cover, distance to water bodies, distance to roads, relative relief and slope angle.

\section{Lithology}

The primary sources of crushed aggregate are various types of rocks such as; basalt, gneiss, dolomite and limestone etc. However, all rocks may not be suitable for crushed aggregate. Thus, keeping this in mind, classification of the various lithologies for their suitability in aggregate was performed for the current study (Table 2). A massive, high cohesion, and homogenous rock like basalt is most suitable for the crushed aggregate and a massive limestone also comes next to basalt (Table 2) (BGS 2019; Leroy et al. 2017; Langer and Knepper 1995). However, deterital rocks such as; sand stone, conglomerate and shale are soft, friable and easily disintegrate and contain heterogeneous layers (Mitchell 2015). Therefore, they are considered as the least suitable for the crushed aggregate (Regessa et al. 2015; Saaty 2008; Gilpin et al.2007). Low cohesive rocks such as alluvium and elluvium products are on the other hand absolutely unsuitable and they were excluded from the results. The rest were placed in between with moderate rating value.

\section{Land-use and land-cover (LULC)}

Most environmental code of practices preserves and protects cultural heritages, archeological sites, caves, religious institutes, monuments and parks and they are absolutely unsuitable for quarry sites. Therefore, these protected LULC, settlement, cave, and artificial structures (power line and Air port field) were excluded and other land uses were assigned rating based on their relative suitability. Particularly, bare land was provided the highest suitability rating but dense forest cover was given the least rating.

\section{Distance to build up areas}

The nearer a quarry site to sensitive areas, the more un-suitable the site is for quarry purpose. Residents living in proximity to quarries can be endangered by dust up to $0.5 \mathrm{~km}$ from the source. Severe concerns about dust were mostly experienced within about 100m of the dust source (Subhasis et al. 2018; EPA Tasmania 2017; Darwish et al. 2011; SOPAC 2005) (Table 2). Therefore, the quarry code of practice (EPA Tasmania 2017), suggested planning authorities need to maintain the separation distances of $1000 \mathrm{~m}$, in areas where regular blasting takes place; however where material is crushed, only $750 \mathrm{~m}$ separation can be maintained and where vibrating screens alone are utilized $500 \mathrm{~m}$; and where no blasting, crushing or screening occurs a distance of $300 \mathrm{~m}$. For this study, the extreme blasting condition is anticipated and a minimum separation distance of $1000 \mathrm{~m}$ is set. Then every $300 \mathrm{~m}$ new classes were established (Table 2). If a quarry site is with in $1000 \mathrm{~m}$ away from settlments, it is very close to the population centers. Thus, they have higher health hazard. In contrary, quarry sites more than $2500 \mathrm{~m}$ from builtup area, are far away from consumers and will have market problem with higher transportation cost. However, an areas between 1000-1300 m are not far nor close, with less hazard and is considered as economical distance (EPA Tasmania 2017). Therefore, this class was provided the highest suitability rating.

\section{Distance to water bodies}

Run off from quarry sites flow very rapidly towards nearby water bodies, thus lakes and streams are susceptible to pollution from quarries (Pal and Mandal 2019). There needs to be strict control of runoff from the quarry sites. The safest way is to leave adequate buffer zones around water-courses and river corridors (Thennakoon 2016) (Table 2). Some quarry code of practice, suggested disturbance should not occur within $40 \mathrm{~m}$ of any watercourses or within 10m of drainage lines (EPA Tasmania 2017). However, this distance is small as it is very short distance for the runoff to enter the watercourse. Thus, in the present study it is modified to $150 \mathrm{~m}$ of minimum separation distance from water bodies and dry streams were excluded because such stream courses will not be vulnerable for the pollution from the quarry site. The water bodies within $150 \mathrm{~m}$ distance from the quarry site is very close and may pose difficulty in managing effluents from the quarry activities. However, a quarry site with more than $600 \mathrm{~m}$ away from the water bodies is relatively far away and pollution from the quarry activities can be managed. Further every $150 \mathrm{~m}$ new classes were established for the present study (Table 2). Thus, suitability ratings were attributed in an increasing order from $150 \mathrm{~m}$ to $600 \mathrm{~m}$ of distance from water courses. 


\section{Distance to road}

An area within $500 \mathrm{~m}$ distance to existing roads is too short distance hence traffic can easily be endangered by the quarry activities (noise, dust, blast rock fragments, vibrations and other quarry operations), thus quarry sites located very close ( $<500 \mathrm{~m})$ to the existing roads will not be suitable. Furthermore, an area more than $7500 \mathrm{~m}$ from existing roads consume more time and fuel for transportation, cause high pollution and requires more budget for access road construction. Hence, it is highly un-economical and not suitable for a quarry site. In contrast, an area in between 500 to $5000 \mathrm{~m}$ is fairly far away with less injury from the quarry activities, less time of transportation and less fuel consumption and requires relatively moderate budget for access road construction. Hence, it is highly economical and highly suitable for the quarry site selection. The rest are areas with an intermediate distance and require moderate budget (Table 2) (Barakat et al. 2016; Gilpin et al. 2007; Robinson et al. 2004). For the assessment of distance to the roads euclidean distance tool in Arc GIS was used and the resulting map is presented as Fig.4 (e).

\section{Relative relief}

A slope having relative relief less than $5 \mathrm{~m}$ may be stable and accessible for quarry operations however, it may have potential for flooding and difficulty in excavation. Thus, suitability for quarry site for relative relief $<5 \mathrm{~m}$ is extremely low and the least rating of 1 is assigned and relative relief more than $200 \mathrm{~m}$ will have low suitability due to challenges in accessibility and difficulties in operation and management of the quarry activities. In contrast, relative relief 5-25 m (very low) and 25-50 m (low) will have extremely high and very high suitability therefore, rating of 7 and 6 are assigned, respectively. The relative relief in between $5-50 \mathrm{~m}$ will provide most suitable conditions for quarry operations by ease of accessibility and excavation (Table 2).

\section{Slope angle}

Slope inclination is responsible for the stability of the slope. Steeper slopes are more susceptible for slope instability (Chimidi et al. 2017; Girma et al. 2015; Raghuvanshi et al. 2015). Besides, steep slope sections will also pose problem for accessibility and difficulties in excavation of rock. Thus, it is reasonable to say that steeper slope sections are not suitable for quarry operations whereas, gentle slope sections are suitable for the quarry operations. The code of practice for small quarries, Department of Primary Industries, Earth Resources, the state of Victoria-Australia (DPIER 2010), recommend a maximum gradient of 1:10 (vertical: horizontal) or slope angle of $5.7^{\circ}$ for haul roads to reduce noise from the use of brakes and/or increased engine power to climb slopes. However, a bit higher slope angle is suitable for the ease of quarry excavation. Therefore, in the present study, slope class of $5-15^{\circ}$ is considered as extremely high suitable class for quarry operation. It can be noted from Table 2 that slope angle class $5-15^{\circ}$ and $15-25^{\circ}$ are considered as extremely high and very high suitability classes, respectively. These classes will provide most suitable conditions for quarry operations by ease of accessibility and excavation. In contrast, slopes with angles $45^{\circ}$ and above will be lower in its suitability owing to difficulties in accessibility and quarry operations. The slope inclinations $<5^{\circ}$ may pose difficulties in quarry operations due to poor drainage, water logging and pitting for excavation.

On the other hand, slope failure occurs when the downward movements of material due to gravity and shear stresses exceed the shear strength. Processes that can lead to a reduction in the shear strengths of a rock mass are increased pore pressure, discontinuity conditions, and orientation in relation to the slope angle, slope geometry and weathering (Raghuvanshi 2019). The shear stress in rock mass may also increase due to excavation at the bottom of the slope, blasting and seismic effects. A slope geometry that affects its stability includes slope height and angle (Chimidi et al. 2017; Raghuvanshi et al. 2014). Slope stability generally decreases with an increase in the height of the slope (Raghuvanshi 2019). As the slope height increases, the shear stress within the toe of slope increases due to added weight. With increasing slope angle, the tangential stress increases which result in an increase in the shear stress thus reducing its stability (Raghuvanshi et al. 2015). Therefore, though slope angle is not the sole factor that causes instability; considering the slope angle in quarry site selection is helpful for the general evaluation of the area. In the current study, the map of slope angle $\left(^{0}\right)$ was auto-generated from ASTER GDEM at $15 \mathrm{~m}$ resolution (Fig.4 (g)).

\section{Preliminary Suitability Map}

All the layers intended to be used as an input to run the suitability analysis were prepared and a weighted overlay tool was used to produce a preliminary suitability map for all lithologies in the study area (Fig.5 (a)). 
In the present study the consistency of the weight for various factors value was found to be 0.02 (Table 3 ). If the CR value is less than or equal to $\mathbf{0 . 1}$, the weights are consistent and reasonably acceptable (Saaty 2008). Therefore, the current weights assigned to various factors are reasonable and acceptable. Further, during the image classification, an accuracy assessment was also carried out and an overall accuracy of $92 \%$ was found which shows that the LULC classification is reasonable.

Slope gradient in terms of the slope angle is equal to Arctan (VD/HD) and the maximum gradient set for haul roads is equal to $5.7^{\circ}$ $\left(\tan ^{-1}(1 / 10)\right)$ as per the Code of Practice for small quarries, Australia, (DPIER 2010). However, as per works of Anbalagan (1992); Barakat et al. (2016); Raghuvanshi et al. (2015); Raghuvanshi et al. (2014), quarry site with a slope angle between 5-15 and relative relief in between $5-25 \mathrm{~m}$ is most suitable. The proposed quarry sites shall be placed on bare (open area) land followed by sand covered bed rock and shrubs (Regessa et al. 2015). For the transportation accessibility and to make the quarry site economically viable, the site should be located 500-1600 m away from the existing roads (Dimopoulou et al. 2013; Robinson et al. 2004). For the quarry site to be environmentally friendly, the proposed site should be located not less than $150 \mathrm{~m}$ away from the water bodies (Kontos et al. 2005; Yoxas et al. 2011). Further, the quarry sites should be located not less than $1000 \mathrm{~m}$ away from the periphery of towns and other build up areas (Dimopoulou et al. 2013; EPP and ASD 1999).

In the present study the results of the weighted overlay analysis have identified four varying degree of suitability classes in the study area. The preliminary suitability map of the study area for all lithologies shows that $136 \mathrm{~km}^{2}(2.75 \%)$ of the area is highly suitable for quarry sites, whereas, $1587 \mathrm{~km}^{2}(32.12 \%)$ of the study area is moderately suitable for quarry sites. The land which has low suitability, accounts for $2166 \mathrm{~km}^{2}$ (43.82\%) of the study area and remaining $1053 \mathrm{~km}^{2}(21.31 \%)$ of the land is classified as unsuitable for the quarry sites (Fig.5 (a) and (b)). The highly suitable areas are dominantly present in the northern (east of DireDawa and north of Kombolcha) and south-eastern (east of Girawa and south of Kurfa Chale) portions of the study area. These areas are mostly covered by massive limestone, bare and shrub lands, moderate to low relative relief and gentle to very gentle slopes. Besides, suitable areas for quarry site are sparsely distributed through the study area.

\section{Conclusions}

GIS and AHP have been combined to select the well suited quarry site in Harer-Dire Dawa area, Eastern Ethiopia. Since optimal site selection for quarry operation is governed by factors such as the availability of suitable lithology, land form, nearness to demand centers, environment and socio-economic considerations; factors such as lithology, land use and land cover, distance to buildup areas, distance to water bodies, distance to roads, relative relief and slope angle were taken into consideration for preliminary quarry site selection. GIS was employed to digitize all the spatial features related to suitably for the quarry site selection and for weighted overlay analysis. Due consideration for all possible factors may facilitate in environmentally friendly and sustainable quarry sites location. In the present study, analysis was carried out to locate the suitable areas for the quarry sites. For each selected factors appropriate classifications were made and criteria were formulated based on suitability for the quarry site selection. In order to assign the weights to each of the considered factors, AHP method of pair-wise comparison matrix was used. Thus, by considering selected factor maps weighted overlay analysis was applied to produce the preliminary quarry site suitability map for the study area for all available lithologies. Also, attempt was made to assess separately the suitable sites for the limestone quarry. This was mainly done with an understanding that the study area is dominated by limestone and limestone is considered to be very suitable rock for aggregate.

The suitability map of the study area for all lithologies shows that $136 \mathrm{~km}^{2}(2.75 \%)$ of the area is highly suitable, $1587 \mathrm{~km}^{2}$ $(32.11 \%)$ of the area is moderately suitable, $2166 \mathrm{~km}^{2}(43.83 \%)$ of the area is low suitable and remaining $1053 \mathrm{~km}^{2}(21.31 \%)$ of land is unsuitable for the quarry sites. The most preferable site is with basalt and massive limestone lithology, and with bare land cover. In addition, the closest distance from existing roads, nearest water body, and nearest build-ups to the location is $500 \mathrm{~m}$, $900 \mathrm{~m}$ and $1000 \mathrm{~m}$, respectively.

The application of GIS and AHP method has helped in solving time consuming challenges which are often associated with the selection of quarry site. The results of the present study highlight priority and non-priority areas quarry sites, considering the likelihood of causing the least and greatest social, environmental and economic disturbances. Besides, the results of the present study will also help in narrowing down the wider study area to suitable areas that may be further focused for later quarry sites selection and detailed field investigation for the suitable quarry sites.

Page $12 / 21$ 
This result will also greatly serve as a guide for quarry site selection in other regions or other developing countries. Environmental planners can easily apply the criteria to spatially buffer unsuitable locations for quarry sites, identify criteria priorities, and select the most suitable site under each criterion. This minimizes social, economic and environmental impacts which results from quarry operation and management. In addition, the output of this particular study can help in guiding investors for further quarry development and also help the permit authorities for anticipating negative impacts, favoring conservation strategies, and expansion of the quarry industry with the least ecosystem disturbance.

However, the proposed approach does not replace the need for a serious and detailed quarry site studies at large scale. It can and should be used to identify areas where the detail studies could focus to gather more precise, technical, and practical information about the quarry site. This strategy can provide more accurate data to support decisions and reduce the time necessary to obtain the required environmental license, which is considered critical for the development quarry industry. Prioritizing environmental and social factors for quarry site selection issues not only ensures sustainable development, but also maintains high levels of organizational productivity as it ensures uninterrupted operations with minimum failure throughout the project's life.

\section{Abbreviations}

AHP: Analytical Hierarchy Process; AOI: Area of interest; Cl: Consistency Index; CR: Consistency Ratio; DEM: Digital Elevation Model; DPIER: Department of Primary Industries, Earth Resources, the state of Victoria-Australia; ERA: Ethiopian Roads Authority; EPA: Environmental Protection Authority; GIS: Geographical Information Systems; GSE: Geological Survey of Ethiopia; LULC: Land use and land cover; RI: Random consistency index; SOPAC: South Pacific Applied Geoscience Commission; UTM: Universal Transverse Mercator.

\section{Declarations}

\section{Acknowledgements}

All kinds of supports extended by Addis Ababa Science and Technology University and Adama Science and Technology University are thankfully acknowledged. The authors are also thankful to Dr. Daniel Alemayehu and Dr. Shanker Karuppannan from Adama Science and Technology University for their technical support and valuable suggestions that has helped in finalizing the present research.

\section{Authors' Contribution}

The $1^{\text {st }}$ author done technical, scientific analysis of the research and developed the manuscript. The $1^{\text {st }}$ co-author read and suggested amendments in the analysis and structure of the manuscript and reviewed the final manuscript. The $2^{\text {nd }}$ and $3^{\text {rd }}$ coauthors reviewed the final manuscript and enhanced the overall quality of the manuscript, including language correction. All authors contributed, read and approved the final manuscript.

\section{Funding}

No funding was used for this manuscript preparation.

\section{Ethics approval and consent to participate}

This manuscript does not contain any individual person's data and ethics approval is not required.

\section{Competing interests}

The authors declare that they have no competing interests.

\section{Authors' detail}

${ }^{1,3}$ Department of Geology, College of Applied Sciences, Addis Ababa Science and Technology University, Addis Ababa, Ethiopia; ${ }^{1}$

${ }^{4}$ Department of Civil Engineering, School of Civil Engineering and Architecture, Adama Science and Technology University, Adama, 
Ethiopia; ${ }^{2}$ School of Earth-Sciences, College of Natural Sciences, Addis Ababa University, Addis Ababa, Ethiopia.

\section{References}

1. Adewumi, J. R., Ejeh, O. J., Lasisi, K. H., \& Ajibade, F. O. (2019). A GIS-AHP-based approach in siting MSW landfills in Lokoja, Nigeria. SN Applied Sciences, 1:1528, 1-

2. Akanwa AO, Okeke FI, Nnodu VC, lortyom TE (2017) Quarrying and its effect on vegetation cover for a sustainable development using high-resolution satellite image and GIS. J Envir Earth Sci 76:1-12.

3. Alanbari MA, Al-Ansari N, Jasim HK (2014) GIS and Multicriteria Decision Analysis for Landfill Site Selection in Al-Hashimyah Qadaa. Natural Sci 6:282-304.

4. Anbalagan R (1992) Landslide hazard evaluation and zonation mapping in mountainous terrain. Eng Geol 32:269-277.

5. Ataei M, Jamshidi M, Sereshki F, Jalali SME (2008) Mining method selection by AHP approach. J Southern Afr Institute of Mining and Metallurgy 108:741-749.

6. Barakat A, Ouargaf Z, Touhami F (2016) Identification of potential areas hosting aggregate resources using GIS method: a case study of Tadla-Azilal Region, Morocco. J Environmental Earth Sci 75:1-

7. Bosellini A, Russo A, Assefa G (2001) The Mesozoic succession of Dire Dawa, Harar Province, Ethiopia. J Afr Earth Sci32:403417.

8. BGS (British Geological Survey) (2019) Construction aggregates. Mineral Planning Factsheet 45:567-568.

9. Chimidi G, Raghuvanshi TK, Suryabhagavan KV (2017) Landslide hazard evaluation and zonation in and around Gimbi town, western Ethiopia - a GIS-based statistical approach. Appl Geomat 9:219-

10. Darwish T, Khater C, Jomaa I, Stehouwer R, Shaban A, Hamze M (2011) Environmental Impact of Quarries on Natural Resources in Lebanon. Land Degrd Develt 22:345-358.

11. Dimopoulou E, Tolidis K, Orfanoudakis Y, Adam K (2013) Spatial multi-criteria decision analysis for site selection of sustainable stone waste disposal. Fresenius Environ Bull 22:2022-2026.

12. DPIER (Department of Primary Industry, Earth Resources Regulation branch) (2010) Code of Practice for Small Quarries of Australia (COPSMA), Melbourne, Victoria, Australia.

13. Ebistu TA, Minale AS (2013) Solid waste dumping site suitability analysis using geographic information system (GIS) and remote sensing for Bahir Dar Town, NW Ethiopia. Afr J Enviro Sci Tech 7:976-989.

14. Egesi N, Nwosu JI (2018) Crushed Rocks and Dimension Stone: Exploration, Evaluation and Exploitation in parts of Igarra Area, Southwestern Nigeria. Int J of Sci 7:10-

15. EPA Tasmania (Environment Protection Authority Tasmania) (2017) Quarry Code of Practice $3^{\text {rd }}$ Edition, DPIPWE-Department of Primary Industries, Parks, Water and Environment, EPA, Hobart, Tasmania.

16. EPP and ASD (Environment protection, planning and Analytical Services Division) (1999) Department of primary industry water and Environment (DPIWE), Quarry Code of practice, Hobart, Tasmania.

17. Ermias B, Raghuvanshi TK, Abebe B (2017) Landslide Hazard Zonation (LHZ) around Alemketema Town, North Showa Zone, Central Ethiopia-A GIS based expert evaluation approach. Jr. Earth Sci. \& Eng. 10: 33-44.

18. GSE (Geological Survey of Ethiopia) (2010) Geology of the Harer areas (NC 38/9). Memoir 21, Addis Ababa.

19. Getahun E (2010) Multi-Criteria approach for choosing appropriate quarry sites around Addis Ababa using GIS and Remote Sensing. MSc Thesis, Addis Ababa University, Addis Ababa, Ethiopia.

20. Gilpin R, Robinson Jr A, Larkins PM (2007) Probabilistic Prediction Models for Aggregate Quarry Siting. Natural Resources Research 16:35-146.

21. Girma F, Raghuvanshi TK, Ayenew T, Hailemariam T (2015) Landslide hazard zonation in Ada Berga District, Central EthiopiaA GIS based statistical approach. of Geomatics 9:25-38.

22. Haile G and Suryabhagavan KV (2019) GIS-based approach for identification of potential rainwater harvesting sites in Arsi Zone, Central Ethiopia, Mod Earth Syst Envir 5:353-

Page 14/21 
23. Jablonsky J (2015) Analysis of selected prioritization methods in the analytic hierarchy process. J Physics: Conf Series, 6:2201-2033.

24. Ketema T (1982) Geological investigations for the construction of a drift for a dynamite store in the dire dawa area. Ministry of Mines and Energy, Ethiopian Institute of Geological Surveys. Note No.

25. Kindiga SW (2017) Environmental and Land Use Impacts of Quarrying along Ngong River in Embakasi. MA Thesis, Nairobi University, Nairobi, Kenya.

26. Kontos TD, Komilis DP, Halvadakis CP (2005) Siting MSW landfills with a spatial multiple criteria analysis methodology. Waste Manag 25:818-832.

27. Kou G, Ergu D, Chen Y, Lin C (2016) Pairwise Comparison Matrix in Multiple Criteria Decision Making. Tech Econ Deve Econ 22:738-765.

28. Kumar P, Ramcharan EK (2008) Analytic hierarchy process helps select site for limestone quarry expansion in Barbados. J Envir Manag 88:1384-1395.

29. Langer WH, Drew LJ, Sachs JS (2004) Aggregate and the Environmet-Production, Construction and Reclamation-AGI Envir Awareness Series.

30. Langer WH, Tucker ML (2003) Specification Aggregate Quarry Expansion-A Case Study Demonstrating Sustainable Management of Natural Aggregate Resources. USGS, Science for a Changing World, pp 1-11.

31. Langer WH, Knepper JDH (1995) Geologic Characterization of Natural Aggregate:A Field Geologist's Guide to Natural Aggregate Resource Assessment, open file report, pp 95-

32. Leroy MNL, Molay TGG, Joseph N, Colince FM, Bienvenu NJM (2017) A Comparative Study of Concrete Strength Using Metamorphic, Igneous, and Sedimentary Rocks (Crushed Gneiss, Crushed Basalt, Alluvial Sand) as Fine Aggregate. J Archit Eng Tech 6:191.

33. Mandal S, Mondal, SS (2016) Analytic Hierarchy Process (AHP) Approach for Selection of Open Cast Coal Mine Project. Int J Indu Eng Rese Develo 7:01-13.

34. Mariappan VEN, Rajan S, John P (2018) Environmental Analysis of Quarry Site in Tamilnadu. Indian J Scie Resea 17:37-

35. Mayunga SD (2018) Suitability Analysis of Satellite Towns Using Saaty Model and Geographical Information System (GIS). J Data Analy Inform Proces 6:1-14.

36. Ming'ate F, Mohamed M (2016) Impact of Stone Quarrying on the Environment and the Livelihood of Communities in Mandera County, Kenya. J Scient Resea Reports 10:1-9.

37. Mitchell C (2015) Construction aggregates: evaluation and specification. British Geological Survey, Nottingham, UK.

38. Ogbonna C, Nwafor F, Ugbogu EA (2019) Physiochemical Properties and Anticipated Performance of Selected Plant Species in Lokpaukwu Quarry Site in Abia State, Nigeria. J Enviro Pollu Human Health 7:7-14.

39. Pal S, Mandal I (2017) Impacts of Stone Mining and Crushing on Stream Characters and Vegetation Health of Dwarka River Basin of Jharkhand and West Bengal, Eastern India. J Enviro Geography 10:11-21.

40. Regessa B, Raghuvanshi TK, Kebede S (2015) Quarry site selection and geotechnical characterization of ballast aggregate for Ambo-ljaji railway project in Central Ethiopia: An integrated GIS and Geotechnical Approach. Eng Geol for Society and Territory 6:329-335.

41. Raghuvanshi TK (2019) Plane failure in Rock slopes-A review on stability analysis techniques, J King Saud Univ-Sci 31:101109.

42. Raghuvanshi TK, Negassa L, Kala PM (2015) GIS based Grid Overlay Method versus Modeling Approach - A Comparative Study for Landslide Hazard Zonation (LHZ) in Meta Robi District of West Showa Zone in Ethiopia. Egypt J Remote sensing and Space Sci. 18:235-250.

43. Raghuvanshi TK, Ibrahim J Ayalew D (2014) Slope stability susceptibility evaluation parameter ( SSEP) rating scheme-An approach for landslide hazard zonation. J Afr Earth Sci 99:595-612.

44. Rajasekhar M, Sudarsana RG, Imran BU, Siddi RR, Pradeep KB, Ramachandra M (2019) Identification of Suitable Sites for Artificial Groundwater Recharge Structures in Semi-arid region of Anantapur District: AHP Approach. Hydrospatial Analysis 3:1-11.

Page $15 / 21$ 
45. Ramík J (2017) Ranking alternatives by pairwise comparisons matrix and priority vector. Scient Annals Econo Busi 64:85-95.

46. Robinson GR, Kapo KE, Raines GL (2004) A GIS Analysis to Evaluate Areas Suitable for Crushed Stone Aggregate Quarries in New England, USA. Natural Reso Rese 13:143-159.

47. Saaty TL (2008) Decision making with the analytic hierarchy process. Int J Services Scie 1:83-98.

48. Saha DC, Padhy PK (2011) Effects of stone crushing industry on Shorea robusta and Madhuca indica foliage in Lalpahari forest. Atmos Pollu Rese 2:463-476.

49. SOPAC 2005 (South Pacific Applied Geoscience Commission) Identification of onshore Aggregate Quarry Sites and Prospects for Quarry Development, Pohnpei Island, Federated states of Micronesia. SOPAC Technical Report, pp 382.

50. Subhasis BS, Giyasuddin S, Arindam R (2018) Economic Importance of Stone Quarrying in Rural Livelihood and Its Impact on Environment: A Case Study of Saltora Block, Bankura, West Bengal. Inter J Scient Rese Reviews, 7(3), 1045-1062.

51. Tan BK (1984) Quarry Site Selection in Malaysia. Bull Inter Asso Eng Geol 29:181-185.

52. Thennakoon S (2016) Development of Suitability Index for Locating Rock Quarrying Sites in SriLanka. Proceedings of the International Forestry and Envronment symposium, Conference paper-Abstract, Session VI-Socio Economic dimensions in Natural Resource management.

53. Vaidya O, Kumar S, (2006) Analytic hierarchy process: An overview of applications. European J Operational Research 169:129.

54. Yoxas G, Samara T, Sargologou L, Stournaras G (2011) Multiple criteria analysis for selecting suitable sites for construction of sanitary landfill based on hydrogeological data; Case study of Kea Island (Aegean Sea, Hellas). Environmental Earth Sciences, Advances in the Research of Aquatic Environment 2:97-

55. Zaruba Q, Mencl V (1976) Engineering Geology, $3^{\text {rd }}$ edition. Elsevier Scientific Publishing Company, Amsterdam, The Netherlands.

56. Zelenović Vasiljević T, Srdjević Z, Bajčetić R, Vojinović Miloradov M (2012) GIS and the analytic hierarchy process for regional landfill site selection in transitional countries: A case study from Serbia. Enviro Manag 49:445-458.

\section{Figures}




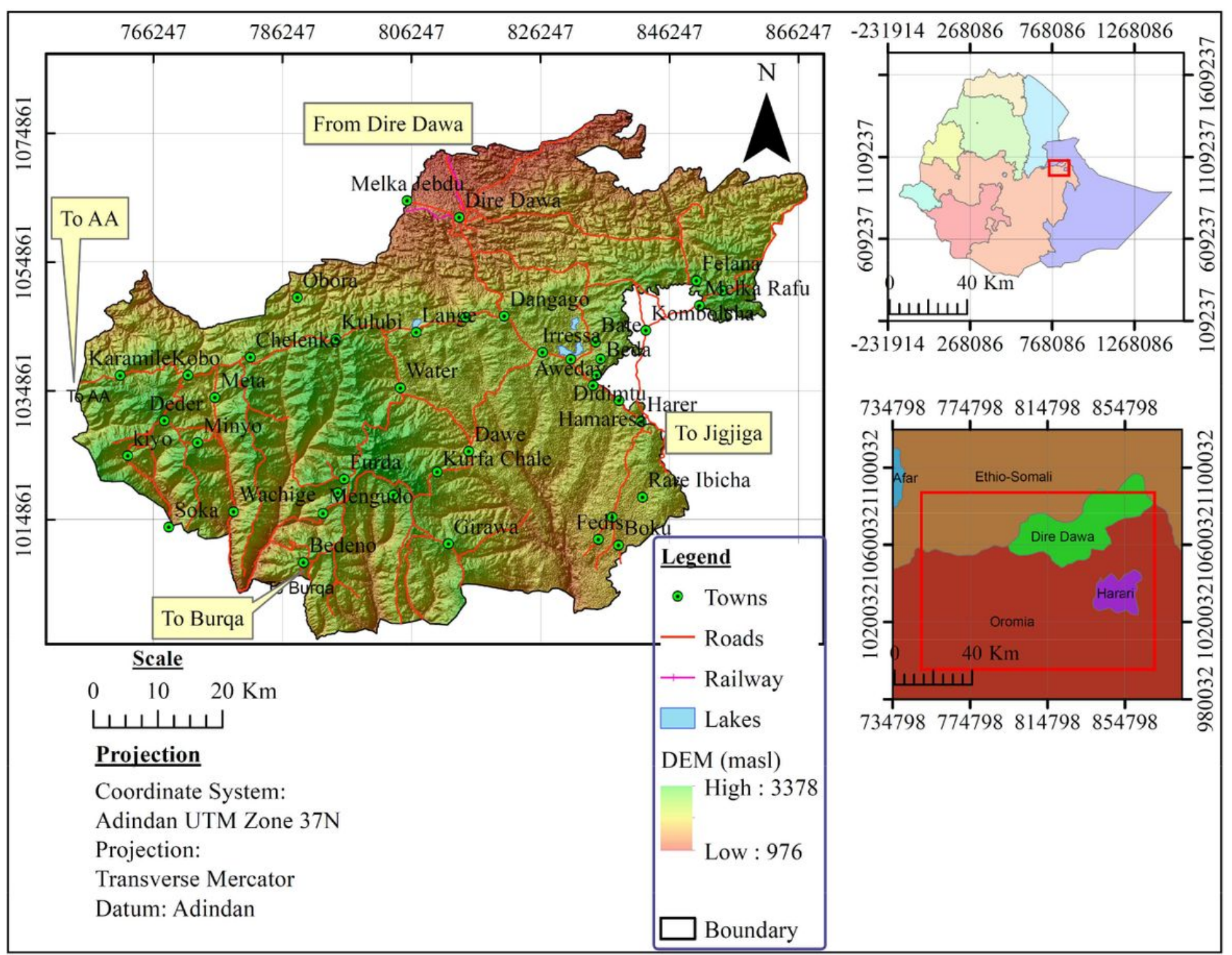

Fig.1

Figure 1

Location map of the study area. 


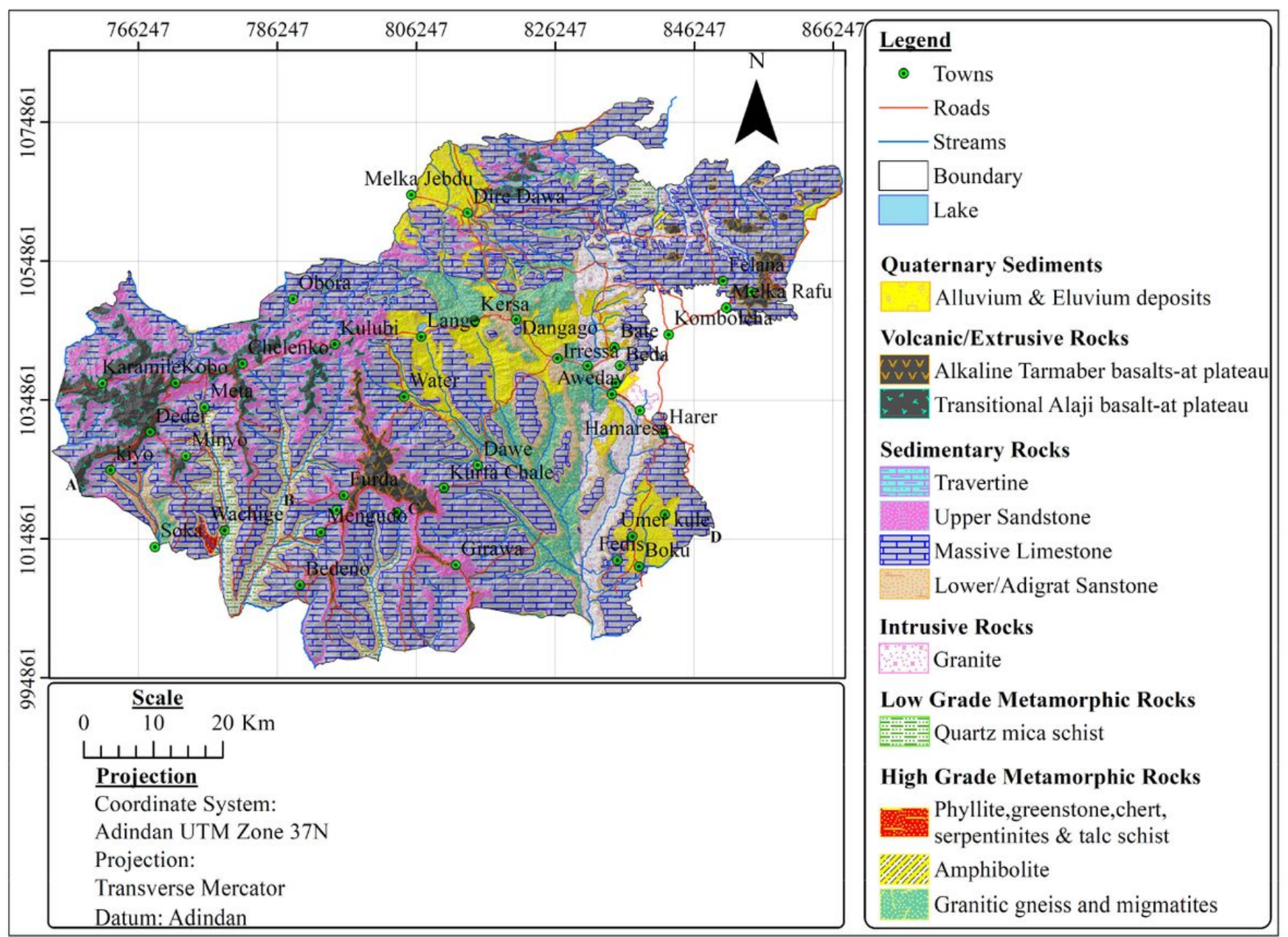

Fig.2

Figure 2

Geological map of the study area 


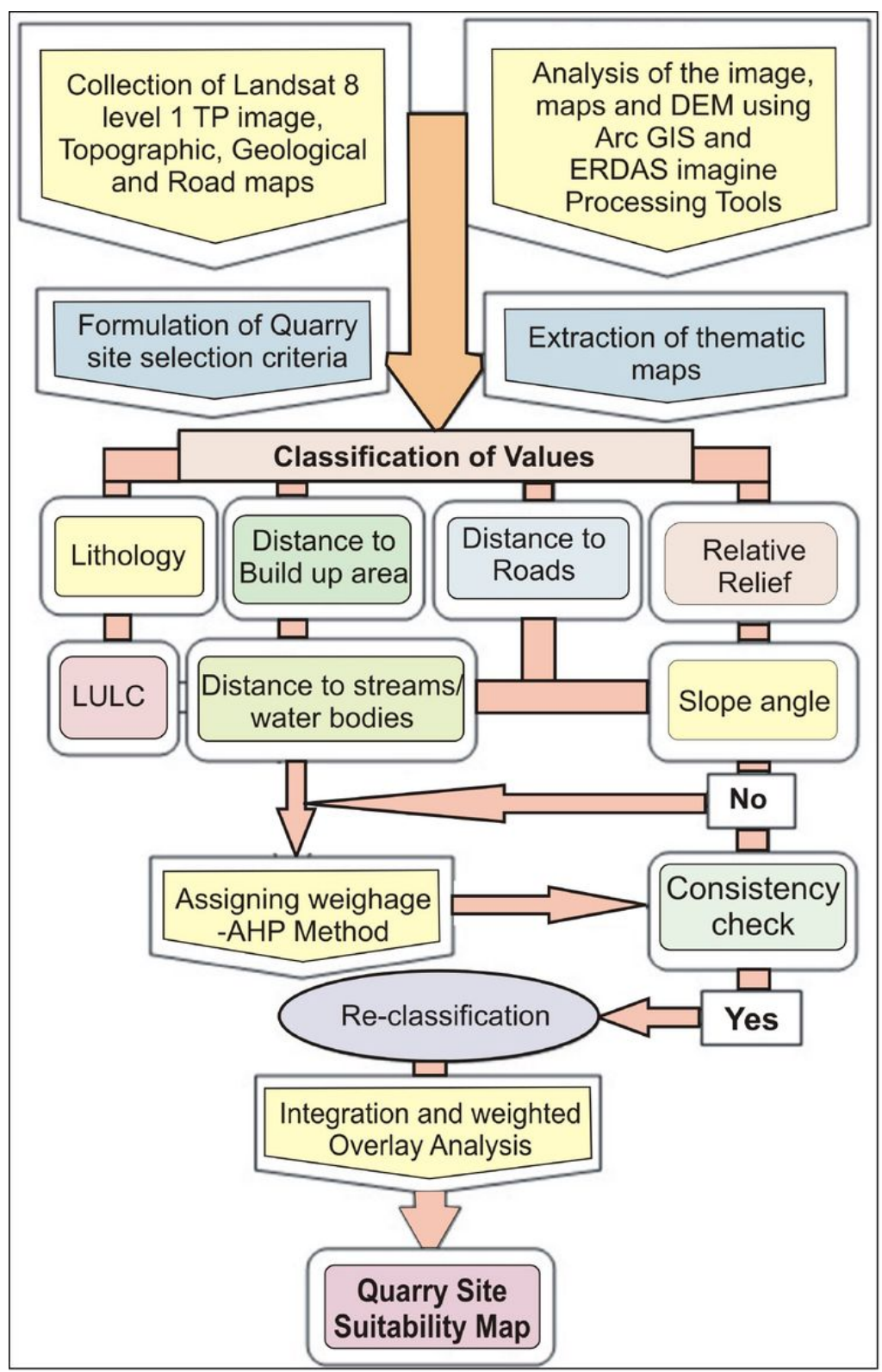

Fig. 3

Figure 3

Methodological flow chart. 


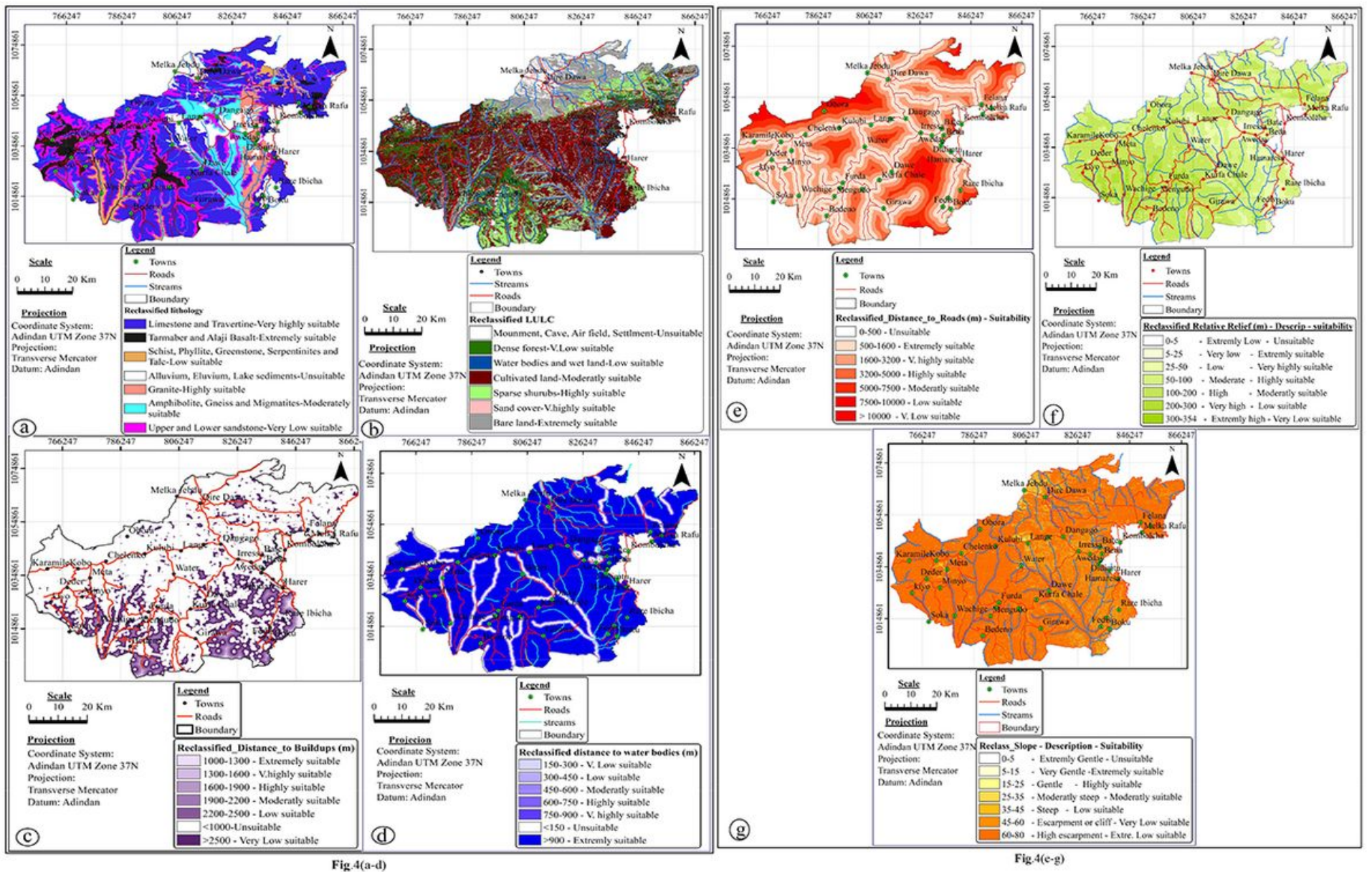

Figure 4

Reclassified maps for (a) lithology (b) land-use and land-cover, (c) distance to build up, (d) distance to water bodies (e) distance to roads, (f) relative relief and $(\mathrm{g})$ slope angle. 


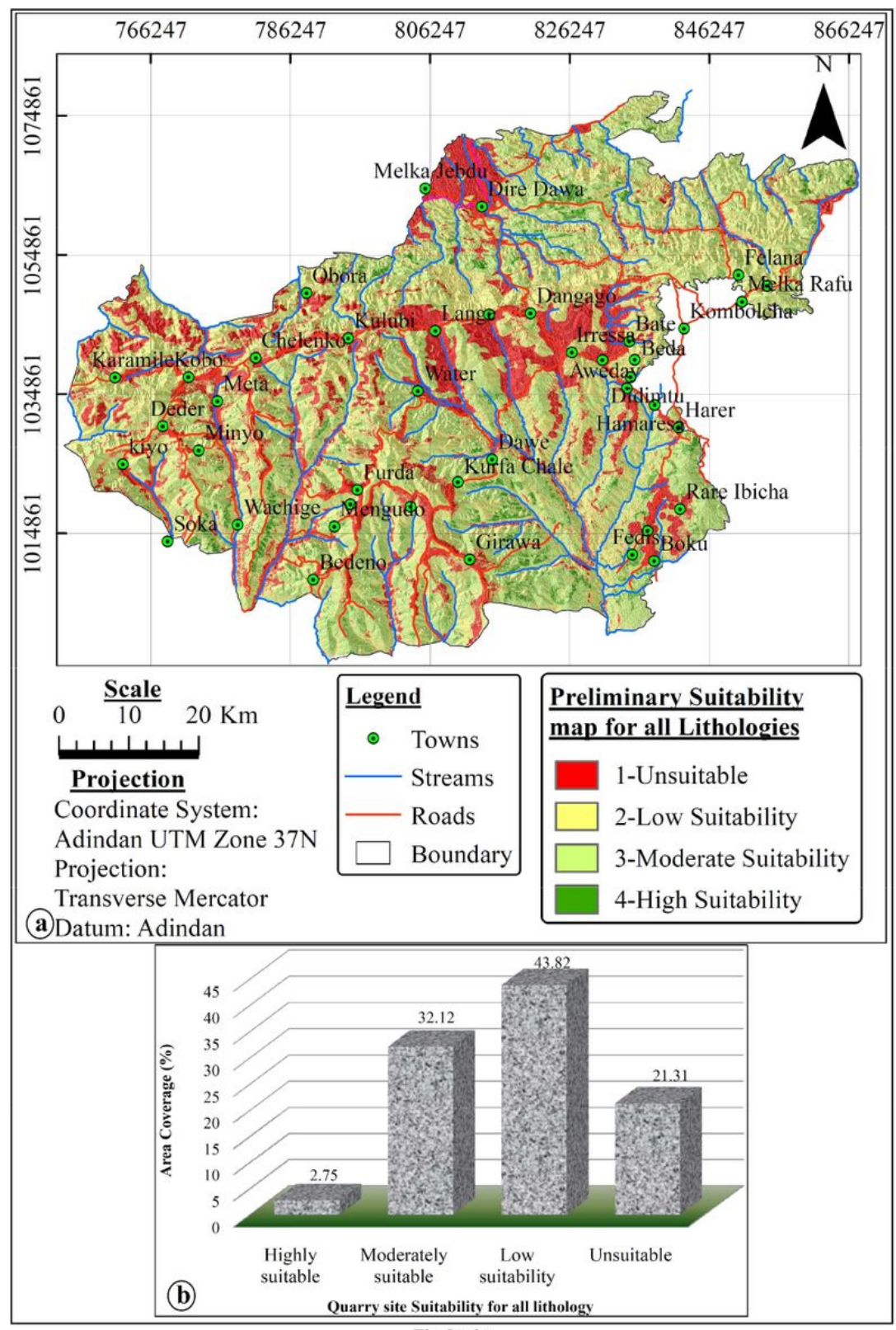

Fig.5(a-b)

\section{Figure 5}

(a) Preliminary quarry site suitability map for all lithologies (b) Percent area suitability for quarry site. 